\title{
Aspiration Formation and Ecological Shocks in Rural Kenya
}

\author{
Martin Paul Jr. Tabe-Ojong ${ }^{1} \cdot$ Thomas Heckelei $^{1} \cdot$ Kathy Baylis $^{2}$
}

Accepted: 12 May 2021 / Published online: 27 May 2021

(c) The Author(s) 2021

\begin{abstract}
Aspirations have been shown to affect households' decisions around productive investments, but little work explores how aspirations are formed or eroded, especially in the face of ecological threats. While ecological threats may erode social and economic capital, there is no consensus on their effect on internal factors such as aspirations. We use the spread of three invasive species as our measure of ecological stressors and shocks. While all three reduce productivity, two of these invasives are slow-moving, and one fast: Parthenium, Prosopis, and Fall Armyworm (FAW), respectively. We ask how exposure to these stressors and shocks affect aspirations about income, assets, livestock, social status, and education as well as an aspirations index. Employing primary data on 530 smallholder households in northern Kenya, we find that ecological stressors, specifically, Prosopis, are correlated with lower aspirations. The effect of ecological stressors on wealth is the mechanism through which this happens. Our findings offer suggestive evidence of the concept of the 'capacity to aspire' which hinges on one's material endowment and relates to the future-oriented logic of development.
\end{abstract}

Keywords Aspirations · Ecological shocks · Stressors · Invasive species · Aspiration index $\cdot$ Kenya

Martin Paul Jr. Tabe-Ojong

tabeojongmartinpaul@gmail.com

Thomas Heckelei

thomas.heckelei@ilr.uni-bonn.de

Kathy Baylis

baylis@ucsb.edu

1 Institute for Food and Resource Economics, University of Bonn, Nussallee 21, 53115 Bonn, Germany

2 University of California, Santa Barbara, USA 


\section{Introduction}

High aspirations may bolster the poor through misfortune and difficulties in their quest for better livelihoods. Many interventions to promote development in rural areas have been unsuccessful because of an imperfect understanding of the desires, expectations, and aspirations of the rural people. A case in point is the low adoption of proven improved farm inputs, techniques and innovations in developing countries (Mausch et al. 2018). Inspired by its direct link to poverty and relevance for specific agricultural interventions especially in rural areas, economists are increasingly studying aspirations. Aspirations have been shown to matter for human capital investments (Beaman et al. 2012; Bernard et al. 2019; Serneels and Dercon 2021), food security (Mekonnen and Gerber 2017), and adaptive capacity by shaping risk management (Rao et al. 2020). Low aspirations and fatalism have been identified as contributing to reduced investments and can lead households to fall into a poverty trap (Macours and Vakis 2014; Laajaj 2017).

In their bid to increase production and improve their livelihoods and welfare conditions, households face a plethora of shocks. These shocks could either be idiosyncratic or systemic and threaten yields of arable crops or pasture productivity. This drop in productivity likely reduces current and future income as well as the value of agricultural assets. In Kenya, the recent spread of three invasive species: two plants (Prosopis juliflora, Parthenium hysterophorus) and one insect (Fall Armyworm) has caused substantial economic harm. In assessing the economic value of dryland ecosystem services affected by Prosopis, Bekele et al. (2018) find that households were willing to pay \$37.74/year for the management of Prosopis, likely due to the loss of productivity and ecosystem services. Parthenium is estimated to generate $\$ 51.4-\$ 81.9$ million in losses, annually in Eastern Africa (Pratt et al. 2017). These losses were projected to increase from $\$ 139.4$ to $\$ 195.3$ million in a 5-10-year period following 2016. In Kenya particularly, current annual losses stemming from Parthenium infestation are estimated to range from $\$ 3.8$ to $\$ 7.7$ million while the predicted future losses range from $\$ 19.1$ to $\$ 28.7$ million (Pratt et al. 2017). With regard to Fall Armyworm (FAW), De Groote et al. (2020) reported that FAW reduced Kenyan maize yields by a third, causing loss of a million tonnes of maize in 2018. These shocks all directly affect current income, but can also portend future productivity losses. While these threats require a coordinated response to evaluate their impact, it is important not only to understand how they affect current outcomes, but how they affect aspirations and future investments.

We use primary household-level data from Kenya to understand the relationship between ecological threats and aspirations. Kosec and Mo (2017) provide a first attempt to shed light on whether environmental threats affect aspirations by analysing floods in rural Pakistan. They report a negative effect of floods on the aspiration of households, with the greatest effect being felt by poor and agriculture-dependent households. We build on their analysis by examining the formation of aspirations under ecological stressors and shocks; specifically 
invasive species. In doing so, we explore possible mechanisms that may underlie the relationship between ecological shocks and aspirations. We test whether these shocks affect incomes and assets, which reflects the 'capacity to aspire' concept of Appadurai (2004). Using invasive species as ecological stressors enables us to worry less about endogeneity concerns as our invasive species pressure can be considered relatively exogenous to the determinants of rural aspirations. However, to address some of the residual endogeneity between ecological shocks and the aspiration measures, we also employ an instrumental variable approach for robustness.

The study offers the following contributions. Firstly, it adds to the aspiration literature by providing empirical evidence on the formation of aspirations under an ecological threat. We study two ecological stressors and one ecological shock (FAW) which pose a short-run threat to income, similar to floods studied by Kosec and Mo (2017). Unlike Kosec and Mo (2017), all three threats we study pose longer-run constraints to productivity and may therefore affect farmers' expectations for the future not only by limiting current income and assets but by causing concerns about future income streams. Given that not all shocks are the same, our main contribution here stems from the fact that we consider three types of invasive species. Secondly, we follow the well-tested instrument on aspiration measurements designed by Bernard and Taffesse (2014), but add livestock as an additional dimension of aspiration to fully capture the rural wealth level of households. As the study area is a pastoral community, livestock represents rural wealth to a considerable extent. In these communities, livestock serves as a measure of status and acts as a means of savings. Livestock are also a productive asset in and of themselves, providing multiple services and commodities including traction power, insurance, wool, and a source of nutritious food (Aryal and Holden 2012). Their droppings are usually used to produce farmyard manure (Debela 2017) which is used to improve agricultural productivity. Livestock also signify and exhibit some cultural values and attributes as they are offered as dowry and presented as gifts during weddings. In this respect, livestock aspirations encompass several dimensions of aspirations.

Finally, we evaluate all five dimensions of aspiration separately and further examine underlying mechanisms. To our knowledge, this study is the first to investigate what drives aspiration formation in each of the quantitative dimensions of aspirations. Potentially, the dimensions to which an individual could aspire are infinite; however, income, wealth, education, and social status are the central dimensions that capture a large share of what the rural poor aspire to, particularly in low- and middle-income countries. Most previous studies (Stutzer 2004; Knight and Gunatilaka 2012; Janzen et al. 2017; Kosec and Mo 2017) only analyse the formation of aggregate aspirations (index approach) or look at the dimensions separately, in which case they focus on at most two dimensions.

The rest of the study is organized as follows: Section two provides a background into ecological shocks and invasive species in Kenya. A conceptual framework that links ecological threats to aspirations is also developed in this section. Section three presents the farm household survey, data collection, and measurement of variables while the empirical strategy is presented in the fourth section. The descriptive and 
empirical results, as well as the tested mechanism, are presented in section five. The article concludes in section six.

\section{Shocks and Aspiration Formation}

\section{Ecological Shock-Invasive Species in Rural Kenya}

Invasive plants and animals are an increasing threat to agricultural production, reducing the yields of crops and pasture. They pose a particular hazard to smallholder farmers and ranchers who may have limited tools to mitigate the damage they cause. They also present a threat to ecosystem functioning, biodiversity, and habitat as they out-compete both planted and natural vegetation (Bekele et al. 2018). While they are non-native to Africa, their spread and incidence are increasingly reported in many African countries, with visible impacts on livelihoods and the environment. Their fast spread and impact can be attributed to allelopathy and competition, allergic response, hypersensitivity inducement, rapid growth, pollen swamping, and easy mode of transportation (CABI 2019). The incidence of these invasive species often forces changes in livelihood beyond losses in crop production, affecting the prospects of households (Pratt et al. 2017). For instance, school-age children may be forced to sacrifice school to spend considerable time managing these invasive species through methods such as weeding, cutting, pruning, and spraying.

As highlighted in the introduction, we consider three invasive species currently impacting the livelihoods of farmers in Kenya: Prosopis, Parthenium, and FAW. Prosopis is a shrubby woody plant native to South America. It was among one of the plant species introduced to Kenya in 1983 by the Food and Agriculture Organization (FAO) to rehabilitate the Arid and Semi-Arid Areas (ASALs) from increasing deforestation, desertification, soil erosion and salinization, and to protect households from wind and dust storms (Mwangi and Swallow 2008). The plant was also introduced for fodder, honey production, shades, windbreaks, fuelwood, firewood, and construction materials with a general objective of improving the livelihood options of households (Mwangi and Swallow 2008). Over time, its pods have been used as feed to livestock and occasionally by humans. However, after establishment, the trees quickly invaded agricultural and rangeland areas, reducing pasture and farmland productivity (Mwangi and Swallow 2008). The tree has also degraded ephemeral wetlands, irrigation canals, leading to the death of livestock, causing floods, and reducing livestock (meat) quality.

In Kenya, these species were specifically introduced in the Marigat division of the Baringo county stretching from Lake Baringo towards Lake Bogoria. Marigat is a low-land area where the invasion of Prosopis can easily be observed. Using Landsat satellite data, Mbaabu et al. (2019) report an increase in Prosopis coverage from 882 hectares in 1988 to 18,792 hectares in 2016 and found that Prosopis directly accounted for over $30 \%$ of the reduction of land use and land cover changes in grasslands, irrigated croplands, rainfed croplands, and vegetation. Their work suggests that Prosopis is a key driver of the observed land use and land cover changes in the Marigat division of Kenya. In 2005, the rural population, frustrated with dwindling 
grazing lands stemming from the Prosopis invasion, filed a lawsuit against the national government of Kenya for the introduction of Prosopis in the area.

Parthenium is an annual herb native to Central and South America, Mexico, and the Southern United States which has increasingly become a rangeland weed in Asia and Africa (CABI 2019). It affects crops, livestock, and biodiversity with effects on animal health and human livelihoods. The effect of Parthenium on crops and forage plants is due to its highly competitive and allelopathic nature which inhibits the growth of a wide variety of crops. Moreover, it also acts as a secondary host for other pests that attack arable crops such as maize, sorghum, and beans. It negatively affects livestock production by reducing grazing land as it encroaches and replaces forage plants, reducing the forage intake of livestock. When animals feed on Parthenium, it leads to poor tasting meat and low milk quality as well as intestinal damage, anorexia, and dermatitis (CABI 2019). From an environmental perspective, Parthenium leads to a loss of biodiversity through a disturbed food chain.

Fall armyworm (Spodoptera frugiperda J: E Smith) is a crop pest first reported in Africa in late 2016 which quickly spread across sub-Saharan Africa (FAO 2018). Native to the Americas, the pest preferably feeds on staple crops such as maize, but also wheat, sorghum, and millet as well as rice and vegetable crops (De Groote et al. 2020). It damages plants by attacking their vegetative growing areas and burrowing into the cobs of older plants reducing both the quality and quantity of the harvested plants. FAW is a migratory pest with a high dispersal capacity that spreads rapidly among its host plants. It has a varying life cycle of 30-80 days depending on the season of the year (Baudron et al., 2019). The warmer the season, the less time it takes to complete its life cycle. Kenya's semi-arid environment, with an extended dry season, is unfortunately highly suitable for the FAW, leading to its high incidence since its arrival.

For an agrarian economy like Kenya where maize is an important staple crop providing food, feed, and income to rural households, the invasion of FAW is a threat to food security and detrimental to rural livelihoods (Kassie et al. 2020). From a household-level perspective, FAW directly affects the income level of households through yield losses and increased cost of production. It also increases farm efforts and the labour costs needed to additionally deal with the pest, making it a threat to maize production with a substantive negative impact on food security and welfare in Kenya.

\section{Conceptual Framework}

Here, we present a simple framework to structure our thinking about the effects of ecological shocks on aspirations and identify possible underlying mechanisms. We see several possible mechanisms: (1) since ecological stressors and shocks affect individual productive activities and thereby economic outcomes, goals that were previously viewed as achievable may no longer seem reachable, causing individuals to adjust their aspirations downward; (2) severe ecological stressors and shocks may increase fatalism in plain sight of the related, emerging risks that increase the probability that investments may not pay off in the future. This perception of 
increased risk could reduce the aspiration associated with large (and risky) investments; (3) ecological stressors and shocks may also impact the community's social and communication structure, which in turn may affect individual aspirations. For instance, approximately 30 years after the introduction of Prosopis in the Baringo county of Kenya by the Food and Agriculture Organization (FAO) with the consent of the government, the rural population filed a lawsuit against the government for introducing this plant despite the original positive benefit it had at the time of its introduction. The communities were dissatisfied with its degree of invasion and its negative impacts on both livestock and human livelihoods. Such community efforts can strengthen community bonds and social networks which can positively affect aspirations.

In most rural communities in Africa, agriculture continues to be the mainstay of many households providing food, income, and employment (Dercon and Gollin 2014). Given agriculture's inherent links to the environment, ecological shocks may have direct consequences on the current income and asset level of households. Thus, we might expect that ecological shocks affect aspirations through their effect on incomes and assets. Zooming in on the effect of ecological shocks on household income, we hypothesize a negative effect between all the invasive species and income. For example, Prosopis affects both crop and livestock farmers negatively, though this could also be seemingly ambiguous given that farmers are increasingly using the trees for charcoal production which could earn them income. Income from beekeeping could also increase given that bee farmers increasingly suspend beehives on mature Prosopis trees (Bekele et al. 2018). The other invasives largely represent negative shocks to farmers as they directly affect the production levels of farmers. Figure 1 shows the interrelationship between shocks and aspirations. It also guides understanding of the specified pathways linking ecological threats and aspirations. From this, some hypotheses arise and are tested in the next sections. In particular, we test the mechanism that the current wealth level of households may mediate how ecological shocks affect aspirations.

\section{Data}

\section{Household Survey Design and Data Collection}

A household survey was conducted between July and August 2019 in the Marigat division of the Baringo county of Kenya. Marigat was purposely selected because of the presence and rapid spread of the invasive Prosopis juliflora and Parthenium hysterophorus coupled with the incidence of FAW. Figure 2 shows the reported infestation levels of invasive species in Marigat. We interviewed 530 households from the Ilchamus, Marigat, Mochongoi, and Ewalel/Chapchap wards of the Marigat division. We used a two-stage sampling procedure wherein villages served as the primary sampling unit. In the first stage, villages were selected using probability proportional to size sampling (PPS). In the selected villages, a household listing exercise was undertaken where we listed all the households in the various villages with the help of the village heads. In the second stage, 15-16 households 


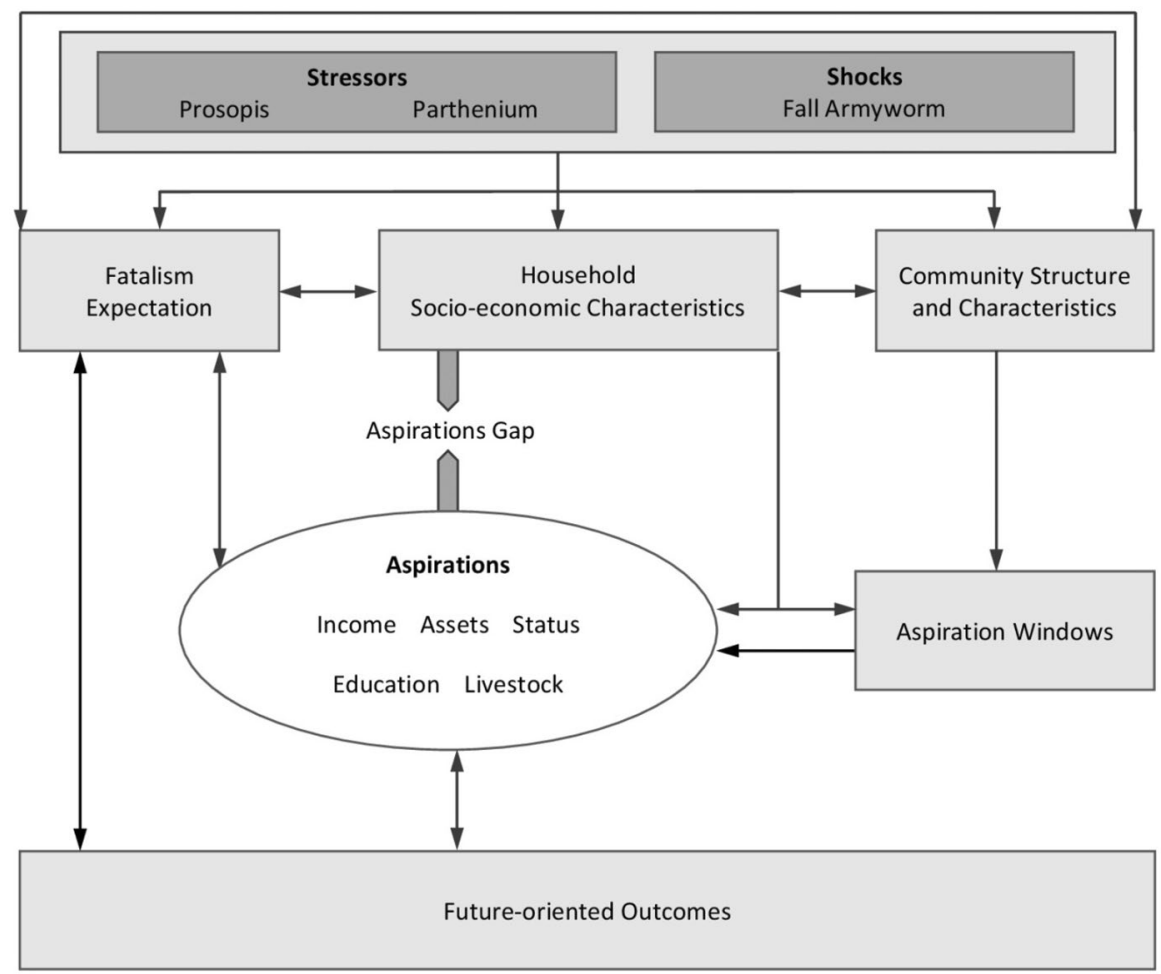

Fig. 1 Conceptual framework linking ecological shocks and aspirations

were randomly selected and interviewed using a structured questionnaire. The survey questionnaire was designed using the World Bank's computer-assisted personal interviewing (CAPI) software, Survey Solutions. The survey was administered through personal interviews by a group of research assistants who were trained and supervised by the first author. Interviews were carried out usually with the household head or the spouse in their local language.

The survey gathered information on the aspirations, hopes, and ecological threats affecting pastoral farmers. Household-level data were garnered on the three invasive species. Data were also collected on key socio-economic variables, institutional characteristics, shocks, and coping strategies, land and livestock ownership, income and expenditure as well as household asset structure. Table 1 describes the main variables used in the analysis.

\section{Measuring Ecological Shocks}

We measure ecological shocks based on the infestation of Prosopis, Parthenium, and FAW over the last calendar year. We used a dummy variable to represent this dichotomous relationship where a value of 1 represents infestation and zero otherwise. In 


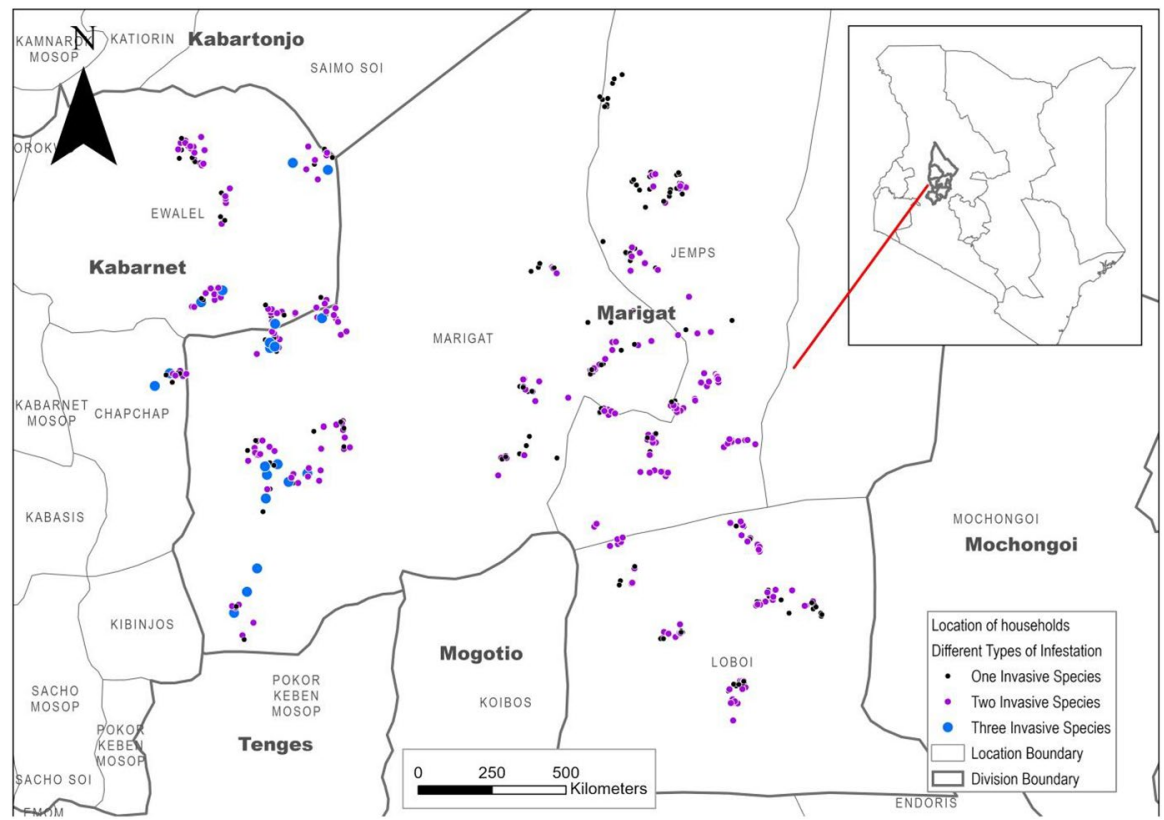

Fig. 2 Infestation levels of invasive species in Marigat, Kenya

the case of FAW, 1 represents FAW infestation while in the case of Parthenium, a value of 1 signifies that fields are infested with Parthenium. As Prosopis is a rangeland invasive, we rather considered infestation based on the neighbourhood of the household. We define the neighbourhood of a household based on a $10 \mathrm{~m}$ radius buffer. It was then captured as an indicator variable that takes the value of 1 for Prosopis infestation and 0 otherwise.

\section{Measuring Aspirations}

Measuring aspirations is a considerable challenge. The multidimensional nature requires different measurement scales rendering comparison and interpretation difficult. The attitudinal nature further challenges the comparability across individuals and studies. The use of different expressions, measurement scales, and the heterogeneity of respondents who may interpret wordings differently may induce measurement error. To address these challenges, we apply the Bernard and Taffesse (2014) aspiration framework measuring aspirations on four key dimensions: income, education, social status, and wealth (see also Kosec and Mo 2017). ${ }^{1}$ While the income and asset aspirations were captured in monetary terms, education aspirations were captured as the number of years of education the parent aspires for their children. ${ }^{2}$

\footnotetext{
1 Note that LaRue et al. (2021) refer to Bernard and Taffesse (2014) as measuring "ambition" instead of aspiration. They understand aspirations as the combination of ambition with the strategy to achieve them.

2 Here, we introduced gender-separated vignettes to capture aspirations for any child below 10 years of age and used fictional children instead of the actual children a household has.
} 
Table 1 Definition of variables

\begin{tabular}{ll}
\hline Variable & Definition \\
\hline Household Income & Total household income (\$) \\
Asset ownership & Total value of all assets (\$) \\
Livestock ownership & Tropical livestock units (TLU) \\
Flock size & Total number of livestock owned \\
Age of the household head & Age of the household head in years \\
Household head is male & $=1$ if household head is male, 0 otherwise \\
Education & Number of years in school \\
Household size & Total number of household members \\
Dependency ratio & Number of dependents over the active population \\
Total cultivated land & Total cropland in hectares \\
Labour & Total labour of all household members (person-days) \\
Hired labour & Total person-days of labour hired \\
Village responsibility & Household head has a responsibility in the village \\
Crop experience & Number of years in crop cultivation \\
Livestock experience & Number of years of livestock keeping \\
Extension contact & Number of interactions with an extension agent \\
Distance to market & Walking distance to the main market (km) \\
Credit access & $=1$ if a household has access to credit facilities, 0 otherwise \\
Mobile money & $=1$ if a household uses mobile money services, 0 otherwise \\
FAW infestation & $=1$ if a household's fields are affected by fall armyworm \\
Parthenium infestation & $=1$ if a household's fields are affected by Parthenium \\
Prosopis infestation & $=1$ if a household's neighbourhood is invaded by Prosopis \\
\hline
\end{tabular}

Source: Author's computation from field survey, 2019

For social status aspirations, we used a 10 scaled status ladder with 1 representing the lowest status aspiration and 10, the highest status aspiration. As our study area is a pastoral community, we added a livestock asset dimension to more fully capture rural wealth aspirations. Here, households reported the actual flock size which we converted to livestock units. As recommended by Bernard and Taffesse (2014), we used well-trained and experienced research assistants so as not to jeopardize the quality of the aspiration data.

We rely on the self-reporting of aspirations. We asked the following questions (in this order) to control for plausible anchoring effects and set a reliable range for reporting household aspirations $a$ ( $a$ being the respective dimension of aspiration):

i. What is the maximum level of $a$ that an individual can attain in your neighbourhood?

ii. What is the minimum level of $a$ that an individual can attain in your neighbourhood?

iii. What is your present level of $a$ ?

iv. What level of $a$ would you like to achieve? 
In enumerator training, we particularly focussed on the difference between aspirations and expectations. ${ }^{3}$ While aspirations are future-oriented, idealistic, and consider one's life goals, expectations are more limited, realistic, and refer to what an individual thinks is more likely about his life after considering potential constraints. A household with a low-income status may likely not expect to increase its income after observing the income of others and considering their income-generating potential. However, this household may still aspire to increase its income.

We expect all five measures of aspirations to be positively related, which would also justify aggregating them to one aspirational index. Despite reducing information on each dimension of aspiration, aggregation controls for measurement error common in attitudinal variables by reducing stochastic noise. First standardization is carried out at the ward level by subtracting the ward's sample average from the aspiration level of each individual in the ward and then dividing by the ward's standard deviation. Then the standardized individual scores are averaged across the aspiration dimensions. Representing an individual's actual aspiration level for dimension $a$ as $x_{i}^{a}$ with $A=5$ being the total number of dimensions, the aspiration index level for each individual $i$ is expressed as

$$
A I_{i}=\frac{1}{A} \sum_{a} \frac{x_{i}^{a}-\mu^{a}}{\sigma^{a}}
$$

$\mu^{a}$ and $\sigma^{a}$ are the ward's sample mean and standard deviation, respectively.

Individuals differ in valuing the different dimensions of aspirations. While some find educational aspiration for their children more important, others may stress social status or asset level more. Since aspirations are motivators for investing resources (effort), it seems relevant to record how individuals regard the importance of the different aspiration dimensions by weighting. To do this, we play a simple game by giving out 20 maize seeds to households asking them to distribute the seeds based on how they value a particular aspiration dimension. The weight $w_{i}^{a}$ is the share of maize seeds associated with a specific dimension. We can then calculate a weighted aspirations index as

$$
A I W_{i}=\sum_{a}\left(\frac{x_{i}^{a}-\mu^{a}}{\sigma^{a}}\right) w_{i}^{a}
$$

\footnotetext{
${ }^{3}$ To be sure that we captured aspirations instead of expectations, we used the Bernard and Tafesse (2014) aspiration framework but translated it during the enumerator training and made it more locally adapted. This was done through extensive discussion with the enumeration team. We also did many pretestings to be sure about this outcome. From the responses to the questions, we are certain households were stating their aspirations as they were multiples of current levels. This is similar to the aspiration levels captured in Janzen et al. (2017).
} 


\section{Measuring the Covariation of Ecological Shocks and Aspirations}

To determine how aspirations vary with ecological shocks, we estimate the following regression:

$$
A i=\beta_{0}+\beta_{1} E S_{i}+\beta_{2} X_{i}+\beta_{3} W_{i}+\varepsilon_{i},
$$

where $A_{i}$ represents the different aspiration dimensions (income, assets, livestock, social status, education) and the aspiration index for household $i, \boldsymbol{E S}_{\boldsymbol{i}}$ is a vector of binary variables indicating infestations with the invasive species (Prosopis, Parthenium, and FAW), $\boldsymbol{X}_{\boldsymbol{i}}$ is the vector of explanatory variables, and $\varepsilon_{i}$ is the stochastic error term. For estimation, we include village fixed effects, $W_{i}$.

Our interest lies in the estimation of $\beta_{1}$ which measures the impact of ecological shocks on the income, asset, livestock, social status, and educational aspirations as well as the aspiration index. We hypothesize a differential effect on the different aspiration dimensions and the index. Of course, ecological shocks should distinctly affect the different dimensions but as they are correlated, a uniform relationship is expected a priori. We consider the spread of ecological shocks as a natural experiment with no household influence. For the income and asset aspiration model, the dependent variable is log-transformed because of its skewed distribution. For the other models, we estimate Eq. (3) in a linear form.

As the incidence of ecological shocks is stochastic, with very little control from households possible, we worry less about endogeneity issues. Ecological shocks are independent of household aspirations. That said, one might be concerned that the intensity of invasives might be correlated with unobservable factors that are also correlated with aspirations. To address this concern, we use village fixed effects and thus identify the effect of these shocks from differences in the intensity of invasives within neighbouring villages. We also include a wide range of control variables.

\section{Results and Discussion}

\section{Descriptive Statistics}

We present the descriptive statistics of some of the important variables used in the empirical model in Tables 2 and 3. While Table 2 presents the means, standard deviation, $10^{\text {th }}$ percentile, and the $90^{\text {th }}$ percentile of the continuous variables, Table 3 presents the frequencies and percentages of the indicator variables. The monthly average household income is approximately $\$ 104.5$, including income from all sources (crop and livestock activities, salaries, remittances, pension, compensation income, and business income). We have three main groups of household assets: total household assets comprising non-productive assets such as television, furniture, buildings, radios; productive assets such as farm implements, ox and donkey carts, ploughs, tractors, and other tools; and livestock assets which include cattle, goats, sheep, donkeys, camel, and poultry. The average 
Table 2 Summary statistics of continuous variables

\begin{tabular}{lrrll}
\hline Variable & Mean & SD & 10th percentile & 90th percentile \\
\hline Household Income (\$) & 104.52 & 127.97 & 19.20 & 216 \\
Asset ownership (\$) & 1646.70 & $10,129.32$ & 76.57 & 2380.56 \\
Productive asset ownership (\$) & 709.56 & 8446.64 & 9.60 & 861.12 \\
Livestock ownership (TLU) & 3.18 & 5.07 & 0 & 7.85 \\
Flock size (number) & 24.74 & 35.16 & 0 & 57 \\
Age of the household head (years) & 45.15 & 15.62 & 26 & 70 \\
Education of head (number) & 7.89 & 4.86 & 0 & 13 \\
Household size (number) & 5.94 & 2.83 & 2 & 10 \\
Dependency ratio & 1.17 & 1.17 & 0 & 2.5 \\
Total cultivated land (hectares) & 0.52 & 0.72 & 0 & 1.21 \\
Off-farm income (\$) & 19.99 & 97.38 & 0 & 38.4 \\
Years in village (number) & 24.46 & 18.68 & 4 & 54 \\
Labour (person-days/year) & 51.32 & 61.62 & 0 & 136.5 \\
Crop experience (years) & 13.4 & 13.02 & 1 & 30 \\
Livestock experience (years) & 17.1 & 16.14 & 1 & 40 \\
Distance to market (Km) & 9.50 & 7.79 & 2 & 20 \\
\hline
\end{tabular}

Source: Author's calculation from field survey, 2019. Income is reported on a per month basis

Table 3 Summary statistics of indicator variables

\begin{tabular}{llllll}
\hline Variable & \multicolumn{2}{l}{ Yes (1) } & & \multicolumn{2}{l}{ No (0) } \\
\cline { 2 - 3 } & Frequency & Percentage & & Frequency & Percentage \\
\hline Household head is male & 393 & 74.15 & & 137 & 25.85 \\
Village responsibility & 89 & 16.79 & & 441 & 83.21 \\
Credit access & 228 & 43.02 & & 302 & 56.98 \\
Mobile money & 438 & 82.64 & & 92 & 17.36 \\
FAW infestation & 390 & 73.58 & & 140 & 26.42 \\
Parthenium infestation & 211 & 39.81 & & 319 & 60.19 \\
Prosopis infestation & 386 & 65.28 & & 184 & 34.72 \\
Irrigation & 128 & 24.15 & & 402 & 75.85 \\
Improved seeds & 333 & 62.83 & & 197 & 37.17 \\
\hline
\end{tabular}

Source: Author's calculation from field survey, 2019

value of the asset holding of households is approximately $\$ 1646.7$ while the productive assets are valued averagely at $\$ 709.6$. Livestock ownership is measured as the herd size and converted to tropical livestock units (TLUs) using the Food and Agricultural Organization (FAO) conversion rate where a cow is equivalent to 0.8 TLU, a goat 0.2 TLU, a sheep 0.2 TLU, and poultry 0.02 TLU. The mean herd size is estimated at 25 with an average TLU of 3.18 . 
Table 4 Summary statistics of aspiration dimensions

\begin{tabular}{lllll}
\hline Variable & Mean & SD & 10th percentile & 90th percentile \\
\hline Income aspiration (\$) & 436.62 & 584.29 & 96 & 960 \\
Asset aspiration (\$) & 8588.26 & $59,715.70$ & 456 & 9600 \\
Livestock aspiration (TLU) & 61.34 & 613.19 & 4.5 & 50 \\
Livestock aspiration (flock size) & 511 & 6131 & 35 & 270 \\
Social status aspiration & 9.00 & 1.11 & 8 & 10 \\
Educational aspiration for boys & 18.10 & 2.45 & 17 & 23 \\
Educational aspiration for girls & 18.12 & 2.18 & 17 & 23 \\
Household Income (\$) & 104.52 & 127.97 & 19.20 & 216 \\
Asset ownership (\$) & 1646.70 & $10,129.32$ & 76.57 & 2380.56 \\
Livestock ownership (TLU) & 3.18 & 5.07 & 0 & 7.85 \\
Flock size (number) & 24.74 & 35.16 & 0 & 57 \\
Social status & 5.78 & 2.02 & 3 & 8 \\
\hline
\end{tabular}

Source: Author's calculation from field survey, 2019. Income and income aspiration are reported on a per month basis

Household demographic characteristics are captured with variables such as age, education, household size, area of cultivated land, off-farm income, labour, and farming experience. The average age of the household head is 45 years and ranges from 18 to 104 years. While almost one-fifth of the household heads have no formal education, the average number of years spent in formal educational training is approximately 8 years. Household size ranges from 1 to 15 members with an average of 5.94 members per household. The dependency ratio measured as the ratio of the number of dependents $(<15$ and $>65)$ to the number of the actively working population (15-64) has a mean value of approximately 1. A great majority of the households are either crop farmers or livestock keepers. The average farm size is 0.52 hectares, suggesting that most of the households are smallholders. Apart from cultivating crops and rearing livestock, households participate in other employment activities earning an average off-farm income of $\$ 19.9$ per year.

Farming experience was also captured with an average crop experience of 13.4 years and an average livestock experience of 17.1 years. Agricultural extension services are not well developed in the study area. Most of the farmers (26\%) are not aware of who/what extension services are. The few who are aware have only interacted with extension agents once on average.

With regard to ecological shocks, about $74 \%$ of the sampled households reported an incidence of FAW in their fields, with about $50 \%$ of crops being damaged by FAW. For the plant invasive species, Parthenium was reported to be new and was described as an 'ambassador'. Its infestation rate was about $40 \%$ with less than $10 \%$ severity with low damage to crops. This can be attributed to the fact that Parthenium only thrives well on plots not extensively managed and along irrigation canals. Though it gets propagated easily because of its tiny seeds, it is easily managed by hand weeding. Prosopis which is mostly found in the lowlands has an infestation rate of about $65.28 \%$. 
Table 5 Pairwise correlations between aspiration measures

\begin{tabular}{|c|c|c|c|c|c|c|}
\hline & Income & Assets & Status & Livestock & Male education & $\begin{array}{l}\text { Female } \\
\text { education }\end{array}$ \\
\hline Income & 1.00 & & & & & \\
\hline Assets & $0.35 * * *$ & 1.00 & & & & \\
\hline Status & $0.15 * * *$ & 0.04 & 1.00 & & & \\
\hline Livestock & 0.01 & 0.01 & $0.10 * * *$ & 1.00 & & \\
\hline Male education & $0.11 * *$ & $0.14 * * *$ & $0.07^{*}$ & $0.13 * * *$ & 1.00 & \\
\hline Female education & $0.15^{* * *}$ & $0.14 * * *$ & 0.05 & $0.12 * * *$ & $0.76^{* * *}$ & 1.00 \\
\hline
\end{tabular}

*p below $0.1, * * * p$ below $0.05, * * * p$ below 0.01 . Author's computation from field survey, 2019

Table 4 presents the mean, percentiles, and standard deviation of our five measures of aspiration and the current levels of the aspiration dimensions. We first recognize that the household's aspirations responses are generally multiples of their current level. On average, the income aspiration of households is $\$ 436.62$, which is 4.2 times their current income level. In a similar vein, households aspire for assets of approximately $\$ 8588.26$, which is 5.2 times their current level of assets. The livestock aspiration of households in terms of TLU is 61.34 while the aspired herd size is approximately 510 (both about 20 times the current level). Social status aspiration has a mean level of 9 and ranges between 4 and 10. While most household heads have little or no level of formal education, their aspired educational level for their children is high. Among households with children less than 10 years of age, irrespective of whether the child is currently enrolled in any formal education or not, the mean aspired education for both boys and girls is 18 years which is equivalent to obtaining an undergraduate degree.

Some significant positive correlations between the different aspiration dimensions exist (see Table 5), but the magnitudes are rather small. This justifies our use of an aspiration index.

\section{Estimation Results}

We use ordinary least squares (OLS) estimations to explore the relationship between ecological shocks and rural aspirations. Tables 6 and 7 below present the effects of ecological shocks on the income, asset, livestock, education, social status, and aspiration index of the households. We begin by evaluating the effect of ecological shocks on the aspirations index. As can be seen in Table 6, Prosopis infestation has a negative impact on the aspiration index. This result echoes the finding of Kosec and Mo (2017) who found the incidence of floods to have a negative effect on the aspirations of households in Pakistan. Prosopis is a direct threat to livelihoods as most households keep livestock. Prosopis can reduce pasture land since it forms huge thickets making it hard for livestock to access common water and feeding points. In the face of this threat, households may become fatalistic and only aspire for less. Furthermore, related to the above and in the light of Kosec and Mo (2017), these shocks may directly impact the welfare and well-being of households. Households 
Table 6 Effect of ecological shocks on aspiration index, income aspiration, and asset aspiration

\begin{tabular}{llll}
\hline & Aspiration index & Income aspirations & Asset aspirations \\
\hline Prosopis infestation (Yes =1) & $-4.339^{* * *}$ & $-0.429^{* * *}$ & $-0.458^{* * *}$ \\
& $(1.635)$ & $(0.109)$ & $(0.147)$ \\
Parthenium infestation (Yes =1) & -0.734 & 0.056 & -0.001 \\
& $(1.230)$ & $(0.079)$ & $(0.119)$ \\
FAW infestation (Yes =1) & -0.308 & -0.129 & -0.048 \\
& $(1.795)$ & $(0.114)$ & $(0.180)$ \\
Constant & $-21.277^{* * *}$ & $8.871^{* * *}$ & $10.848^{* * *}$ \\
& $(4.759)$ & $(0.318)$ & $(0.317)$ \\
$F$-statistic & $5.11^{* * *}$ & $16.46^{* * *}$ & $15.73^{* * *}$ \\
$R$ squared & 0.186 & 0.333 & 0.311 \\
Other controls & Yes & Yes & Yes \\
Village fixed effects & Yes & Yes & Yes \\
Number of observations & 530 & 530 & 530 \\
\hline
\end{tabular}

Robust standard errors are in parentheses. Other controls include knowledge of FAW, age of the household head, education level of the household head, household size, access to credit, extension contact, area of cultivation, livestock ownership, radio ownership, and mobile phone ownership

$* p$ below $0.1, * * p$ below $0.05, * * * p$ below 0.01 . Full results are presented in the appendix

Table 7 Effect of ecological shocks on livestock, status, and educational aspirations

\begin{tabular}{|c|c|c|c|c|}
\hline & \multirow[t]{2}{*}{ Livestock aspirations } & \multirow[t]{2}{*}{ Status aspirations } & \multicolumn{2}{|c|}{ Educational aspirations } \\
\hline & & & Boys & Girls \\
\hline Prosopis infestation $($ Yes $=1)$ & $\begin{array}{l}-0.188 \\
(0.156)\end{array}$ & $\begin{array}{l}-6.552 \\
(16.477)\end{array}$ & $\begin{array}{l}-0.393 \\
(0.320)\end{array}$ & $\begin{array}{l}-0.223 \\
(0.393)\end{array}$ \\
\hline Parthenium infestation $($ Yes $=1)$ & $\begin{array}{l}0.157 \\
(0.104)\end{array}$ & $\begin{array}{l}99.567 \\
(71.088)\end{array}$ & $\begin{array}{l}0.190 \\
(0.221)\end{array}$ & $\begin{array}{l}0.165 \\
(0.217)\end{array}$ \\
\hline FAW infestation $($ Yes = 1) & $\begin{array}{l}0.149 \\
(0.164)\end{array}$ & $\begin{array}{l}45.966 \\
(37.775)\end{array}$ & $\begin{array}{l}0.127 \\
(0.273)\end{array}$ & $\begin{array}{l}0.201 \\
(0.284)\end{array}$ \\
\hline Constant & $\begin{array}{l}8.395 * * * \\
(0.392)\end{array}$ & $\begin{array}{l}-225.22 \\
(231.32)\end{array}$ & $\begin{array}{l}15.251 * * * \\
(1.003)\end{array}$ & $\begin{array}{l}14.938 \text { *** } \\
(1.218)\end{array}$ \\
\hline F-statistic & $2.30 * * *$ & $16.46 * * *$ & $3.54 * * *$ & $3.25^{* * *}$ \\
\hline R squared & 0.065 & 0.049 & 0.116 & 0.093 \\
\hline Village fixed effects & Yes & Yes & Yes & Yes \\
\hline Number of observations & 530 & 530 & 530 & 530 \\
\hline
\end{tabular}

Robust standard errors are in parentheses. Other controls include knowledge of FAW, age of the household head, education level of the household head, household size, access to credit, extension contact, area of cultivation, livestock ownership, radio ownership, and mobile phone ownership

$* p$ below $0.1,{ }^{* *} p$ below $0.05, * * * p$ below 0.01 . Full results are presented in the appendix

may only visualize a bleak future in the face of these ecological shocks, as foreshadowed by their current investment losses. These effects may even be reinforcing, inducing households to aspire for less even when the shocks are past. In line with this result, Jensen (2000) earlier highlighted that households who previously 
Table 8 Ecological shocks on Income and assets

\begin{tabular}{lll}
\hline & Income & Assets \\
\hline Prosopis infestation (Yes =1) & $-0.311^{* * *}$ & $-0.385^{* * *}$ \\
& $(0.113)$ & $(0.152)$ \\
Parthenium infestation (Yes =1) & 0.042 & -0.090 \\
& $(0.134)$ & $(0.149)$ \\
FAW infestation (Yes = 1) & -0.089 & -0.014 \\
Constant & $(0.151)$ & $(0.150)$ \\
& $7.001 * * *$ & $7.279 * * *$ \\
$F$-statistic & $(0.451)$ & $(0.616)$ \\
$R$ squared & $16.50 * * *$ & $12.75 * * *$ \\
Village fixed effects & 0.312 & 0.382 \\
Number of observations & Yes & Yes \\
\hline
\end{tabular}

Notes: Robust standard errors are in parentheses. Other controls include knowledge of FAW, age of the household head, education level of the household head, household size, access to credit, extension contact, area of cultivation, livestock ownership, radio ownership, and mobile phone ownership

${ }^{*} p$ below $0.1, * * p$ below $0.05, * * * p$ below 0.01 . Full results are presented in the appendix

experienced an adverse weather shock depicted lower investments in the education and health of their children.

Looking separately into the five dimensions of aspiration, we find Prosopis infestation to have a negative and significant relationship with income and asset aspirations (Tables 6 and 7). As our income and asset outcomes are log-transformed, households that suffer the threat of Prosopis infestation have income and asset aspirations lower than households with no Prosopis infestation by 42.9 and $45.8 \%$, respectively. As the spread of Prosopis can decimate household assets, these results are expected. Aspiring for many livestock in the future may seem lofty in the face of Prosopis with its harmful effects on livestock, leading to bad quality meat which has market consequences and overall income implications.

The fact that Prosopis has been around for a long time may mean that households perceive it less as a 'shock' but more as a permanent decrease in productivity, which might be why it is having a stronger effect on aspirations. The other shocks also appear to have a negative effect on the index as well as income and asset aspirations but the results are not significant.

\section{Mechanism}

We follow the conceptual framework developed in Sect. 2 to explore the possible mechanism linking ecological shocks and aspirations. We empirically test this framework using the households' current income and asset status as the mediating factors between ecological shocks and aspirations. To do this, we regress income and assets on the ecological stressors and shock along with other model 
Table 9 Income/asset and aspiration index

\begin{tabular}{ll}
\hline & Aspiration index \\
\hline Income & $2.050^{* * *}$ \\
& $(0.530)$ \\
Asset & $0.295^{* * *}$ \\
& $(0.395)$ \\
Constant & $-21.277^{* * *}$ \\
& $(4.759)$ \\
$R$-statistic & $9.35^{* * *}$ \\
$R$ squared & 0.136 \\
Other controls & Yes \\
Village fixed effects & Yes \\
Number of observations & 530 \\
\hline
\end{tabular}

Robust standard errors are in parentheses. Other controls include the age of the household head, education level of the household head, household size, access to credit, extension contact, area of cultivation, livestock ownership, radio ownership, and mobile phone ownership

*p below $0.1, * * p$ below $0.05, * * * p$ below 0.01

variables. The results, presented in Table 8 show a negative association between ecological shocks and the current income and asset levels of households. Ecological stressors and shocks may have in fact caused a reduction in household income, as expected. While income reduced by about $31 \%$, assets have reduced by $38 \%$. The results thus confirm that the current wealth status of households may just be a pathway between ecological shocks and aspirations.

Previous empirical analysis has found that the current income and asset level of households matter in the formation of aspirations. This insight goes back to the concept of 'capacity to aspire' (Appadurai 2004), where low-income households usually aspire for less owing to their present conditions which make them fatalistic. Similar insights have been reported by Stutzer (2004), Janzen et al. (2017), Knight and Gunatilaka (2012), and Kosec and Mo (2017) in their various attempts to understand aspiration formation.

We further test the relationship between the current income and asset levels of households and the aspirations index. As our sample primarily consists of smallholder farmers who live close to or below the poverty line, our findings here reflect some parts of the behavioural poverty trap (Haushofer and Fehr 2014) which alludes to the empirical evidence presented above. Simply put, poverty can affect behavioural outcomes such as aspirations which can further affect futureoriented outcomes which have implications on one's poverty. From the results in Table 9, income and asset holdings of households are positively associated with the aspiration index. This finding, although largely suggestive further confirms the endowment increasing effects on aspirations. That said, it should be noted that other mechanisms may exist but due to limited data, we only tested the income mechanism. 
Table 10 Effect of ecological shocks on aspiration index, income aspiration, and asset aspiration

\begin{tabular}{llll}
\hline & Aspiration index & Income aspirations & Asset aspirations \\
\hline Prosopis infestation (Yes =1) & $-9.772 * * *$ & $-0.448^{* * *}$ & $-1.010^{* * *}$ \\
& $(4.360)$ & $(0.351)$ & $(0.326)$ \\
Parthenium infestation (Yes = 1) & -0.761 & 0.056 & 0.020 \\
& $(1.224)$ & $(0.078)$ & $(0.106)$ \\
FAW infestation (Yes =1) & -0.581 & -0.130 & -0.086 \\
& $(1.648)$ & $(0.105)$ & $(0.143)$ \\
Constant & $-19.142 * * *$ & $8.879 * * *$ & $9.183 * * *$ \\
& $(4.933)$ & $(0.331$ & $(0.429)$ \\
F-statistic & $4.69 * * *$ & $26.56 * * *$ & $8.39 * * *$ \\
Village fixed effects & Yes & Yes & Yes \\
Number of observations & 530 & 530 & 530 \\
\hline
\end{tabular}

Robust standard errors are in parentheses. Other controls include knowledge of FAW, age of the household head, education level of the household head, household size, access to credit, extension contact, area of cultivation, livestock ownership, radio ownership, and mobile phone ownership

$* p$ below $0.1, * * p$ below $0.05, * * * p$ below 0.01 . Full results are presented in the appendix

\section{Robustness Check}

We perform a robustness check to confirm the findings of the study. We employ an instrumental variable (IV) approach to control for the potential endogeneity of Prosopis. While Parthenium and FAW are recent ecological shocks in the study area, one could argue that the case of Prosopis may be different, especially as it was introduced in the area. Thus, one might be concerned that Prosopis intensity is less likely to be randomly distributed, and more likely to be correlated to aspirations through unobservables. An appropriate instrument should determine Prosopis infestation but have no direct effect on the outcome variables (aspirations). As the growth and spread of Prosopis depend on the soil condition, we exploit the soil type where Prosopis infestation is observed as the instrument. Prosopis thrives best on almost all but rocky soils. It survives by extending its trunk very deep to obtain water, which is seemingly impossible in rocky soils. Our data show us a positive and highly significant correlation between soil type and Prosopis infestation (Table A6). We argue that our instrument influences aspirations only through its effect on Prosopis infestation and maintain instrument admissibility. We also performed some correlation analysis to further confirm the admissibility of the instrument (Appendix Table A7).

The results of the IV regressions as shown in Tables 10 and 11 confirm the findings from the OLS model. When aggregating the reported aspiration dimension into an index, Prosopis invasion exhibits a negative relationship with this index. For the individual dimensions, negative significant associations are also observed for both income and asset aspirations. This is also the case with the other dimensions, though the negative associations are not statistically significant. Summarily, the IV regressions also confirm the negative relationship between ecological shocks and aspirations. 
Table 11 Effect of ecological shocks on livestock, status, and educational aspirations

\begin{tabular}{lllll}
\hline & Livestock aspirations & Status aspirations & \multicolumn{2}{l}{ Educational aspirations } \\
\cline { 4 - 5 } & & & Boys & Girls \\
\hline Prosopis infestation (Yes=1) & -50.711 & -0.420 & -1.021 & -0.139 \\
& $(147.546)$ & $(0.395)$ & $(1.103)$ & $(1.026)$ \\
Parthenium infestation (Yes =1) & 99.380 & 0.156 & 0.187 & 0.166 \\
& $(60.870)$ & $(0.109)$ & $(0.234)$ & $(0.240)$ \\
FAW infestation (Yes =1) & 43.940 & 0.138 & 0.098 & 0.205 \\
Constant & $(81.490)$ & $(0.147)$ & $(0.316)$ & $(0.324)$ \\
& -207.122 & $8.489 * * *$ & $15.505 * * *$ & $14.904 * * *$ \\
F-statistic & $(239.536)$ & $(0.447)$ & $(0.995)$ & $(1.008)$ \\
Village fixed effects & $8.65 * * *$ & $20.36 * * *$ & $6.32^{* * *}$ & 7.26 \\
Number of observations & Yes & Yes & Yes & Yes \\
\hline
\end{tabular}

Robust standard errors are in parentheses. Other controls include knowledge of FAW, age of the household head, education level of the household head, household size, access to credit, extension contact, area of cultivation, livestock ownership, radio ownership, and mobile phone ownership

$* p$ below $0.1, * * p$ below $0.05, * * * p$ below 0.01 . Full results are presented in the appendix

\section{Conclusion}

In this article, we sought to understand how households form their aspirations under ecological stressors and shock measured by the incidence of Prosopis, Parthenium, and FAW. We used five rural aspiration dimensions: income, asset, livestock, status, and education as well as an aspiration index to capture the overall aspiration feeling of households. We employ primary data of 530 households in the Marigat division of Kenya. Exploring the household survey data reveals the existence of significant differences between households that are affected by ecological shocks and households that are not. These significant differences spread across a range of farm and household characteristics.

Employing regression approaches to identify the effect of ecological shocks on aspirations, we establish a negative relationship between ecological shocks and aspirations. Furthermore, different ecological shocks have varying effects on the different dimensions of aspirations. Households that face Prosopis infestation have lower income, assets, and livestock aspirations than households without infestation. This could be attributed to the negative effects of these stressors and shocks on the income status of households given that most households are smallholder farmers. Based on this, it may be inconclusive to understand aspiration formation without understanding the current wealth status of households which forms the basis of the capacity to aspire concept. This study offers empirical support to the theoretical concept of 'capacity to aspire' based on the tested mechanism.

Understanding how best to facilitate resilience to ecological stresses and shocks requires an understanding of how these shocks affect attitudes and behaviour. To the extent that current income and asset levels affect aspirations, poverty reduction strategies such as social safety nets and cash transfer interventions should be encouraged. 
Our results are suggestive that poorer households, when faced with an ecological shock, may be driven to a downward aspirational spiral, landing them into a poverty trap. While it is beyond the scope of this study to establish how such relief social protection programs attenuate constraints to the formation of aspirations, we believe that a well-targeted program that seeks to increase the income of rural households will in a way increase their aspirations for the future.

Two limitations of this study could be taken up in future research. Firstly, despite dealing with endogeneity by specifying IV regressions, we cannot claim to have fully identified causal impacts given the cross-sectional nature of the data making it hard to address all potential biases. The use of experimental approaches or panel data may offer better causal identification and should be explored. Moreover, as aspirations evolve over time, panel data offer additional advantages by controlling for unobserved heterogeneities. Secondly, we used five aspiration dimensions that pertain to most rural livelihoods. However, aspirations span through many more dimensions like health, security, and nutrition. Future research in this direction may want to address other dimensions of rural aspirations. That notwithstanding, this analysis is one of the first to quantify aspirations and establish the links between ecological shocks and aspiration based on five aspiration dimensions. As context matters, follow-up research is warranted to test these empirical findings and add to the literature on aspiration formation in rural communities.

\section{Appendix}

See Appendix Tables 12, 13, 14, 15, 16, 17, 18. 
Table 12 Effect of ecological shocks on aspiration index, income aspiration, and asset aspiration (full results)

\begin{tabular}{|c|c|c|c|}
\hline & Aspiration index & Income aspirations & Asset aspirations \\
\hline Prosopis infestation & $\begin{array}{l}-4.339 * * * \\
(1.635)\end{array}$ & $\begin{array}{l}-0.429 * * * \\
(0.109)\end{array}$ & $\begin{array}{l}0.458 * * * \\
(0.147)\end{array}$ \\
\hline Parthenium infestation & $\begin{array}{l}-0.734 \\
(1.230)\end{array}$ & $\begin{array}{l}0.056 \\
(0.079)\end{array}$ & $\begin{array}{l}-0.001 \\
(0.119)\end{array}$ \\
\hline FAW infestation & $\begin{array}{l}-0.308 \\
(1.795)\end{array}$ & $\begin{array}{l}-0.129 \\
(0.114)\end{array}$ & $\begin{array}{l}-0.048 \\
(0.180)\end{array}$ \\
\hline FAW knowledge & $\begin{array}{l}-5.835^{* * *} \\
(2.851)\end{array}$ & $\begin{array}{l}-0.183 \\
(0.203)\end{array}$ & $\begin{array}{l}0.124 \\
(0.228)\end{array}$ \\
\hline Age of the household head & $\begin{array}{l}-0.061 \\
(0.051)\end{array}$ & $\begin{array}{l}-0.005 \\
(0.003)\end{array}$ & $\begin{array}{l}-0.004 \\
(0.004)\end{array}$ \\
\hline Education of the household head & $\begin{array}{l}0.440 * * * \\
(0.172)\end{array}$ & $\begin{array}{l}0.056 * * * \\
(0.009)\end{array}$ & $\begin{array}{l}0.061 * * * \\
(0.013)\end{array}$ \\
\hline Household size & $\begin{array}{l}-0.047 \\
(0.215)\end{array}$ & $\begin{array}{l}-0.003 \\
(0.013)\end{array}$ & $\begin{array}{l}0.075 * * * \\
(0.021)\end{array}$ \\
\hline Access to credit & $\begin{array}{l}1.298 \\
(1.178)\end{array}$ & $\begin{array}{l}0.009 \\
(0.072)\end{array}$ & $\begin{array}{l}0.301 * * * \\
(0.107)\end{array}$ \\
\hline Extension contact & $\begin{array}{l}0.961 \\
(1.308)\end{array}$ & $\begin{array}{l}0.135 \\
(0.084)\end{array}$ & $\begin{array}{l}0.155 \\
(0.121)\end{array}$ \\
\hline Area of cultivation & $\begin{array}{l}0.874 \\
(0.537)\end{array}$ & $\begin{array}{l}0.026 \\
(0.024)\end{array}$ & $\begin{array}{l}0.026 \\
(0.033)\end{array}$ \\
\hline Livestock ownership & $\begin{array}{l}0.358^{* * * *} \\
(0.142)\end{array}$ & $\begin{array}{l}0.020 * * * \\
(0.007)\end{array}$ & $\begin{array}{l}0.064 * * * \\
(0.009)\end{array}$ \\
\hline Radio ownership & $\begin{array}{l}0.763 \\
(1.320)\end{array}$ & $\begin{array}{l}0.020 \\
(0.074)\end{array}$ & $\begin{array}{l}0.170 \\
(0.118)\end{array}$ \\
\hline Mobile phone ownership & $\begin{array}{l}1.709 \\
(1.437)\end{array}$ & $\begin{array}{l}0.074 \\
(0.115)\end{array}$ & $\begin{array}{l}0.126 \\
(0.143)\end{array}$ \\
\hline Constant & $\begin{array}{l}-21.277 * * * \\
(4.759)\end{array}$ & $\begin{array}{l}8.871 * * * \\
(0.318)\end{array}$ & $\begin{array}{l}10.848 * * * \\
(0.317)\end{array}$ \\
\hline$F$-statistic & $5.11 * * *$ & $16.46 * * *$ & $15.73 * * *$ \\
\hline$R$ squared & 0.186 & 0.333 & 0.311 \\
\hline Village fixed effects & Yes & Yes & Yes \\
\hline Number of observations & 530 & 530 & 530 \\
\hline
\end{tabular}

*p below $0.1, * * p$ below $0.05, * * * p$ below 0.01 . Standard errors are in parentheses 
Table 13 Effect of ecological shocks on livestock, status, and educational aspirations (full results)

\begin{tabular}{|c|c|c|c|c|}
\hline & \multirow[t]{2}{*}{ Livestock aspirations } & \multirow[t]{2}{*}{ Status aspirations } & \multicolumn{2}{|c|}{ Educational aspirations } \\
\hline & & & Boys & Girls \\
\hline Prosopis infestation & $\begin{array}{l}-0.188 \\
(0.156)\end{array}$ & $\begin{array}{l}-6.552 \\
(16.477)\end{array}$ & $\begin{array}{l}-0.393 \\
(0.320)\end{array}$ & $\begin{array}{l}-0.223 \\
(0.393)\end{array}$ \\
\hline Parthenium infestation & $\begin{array}{l}0.157 \\
(0.104)\end{array}$ & $\begin{array}{l}99.567 \\
(71.088)\end{array}$ & $\begin{array}{l}0.190 \\
(0.221)\end{array}$ & $\begin{array}{l}0.165 \\
(0.217)\end{array}$ \\
\hline FAW infestation & $\begin{array}{l}0.149 \\
(0.164)\end{array}$ & $\begin{array}{l}45.966 \\
(37.775)\end{array}$ & $\begin{array}{l}0.127 \\
(0.273)\end{array}$ & $\begin{array}{l}0.201 \\
(0.284)\end{array}$ \\
\hline FAW knowledge & $\begin{array}{l}-0.173 \\
(0.262)\end{array}$ & $\begin{array}{l}-7.366 \\
(29.632)\end{array}$ & $\begin{array}{l}-0.531 \\
(0.624)\end{array}$ & $\begin{array}{l}-0.418 \\
(0.573)\end{array}$ \\
\hline Age of the household head & $\begin{array}{l}0.009 \\
(0.042)\end{array}$ & $\begin{array}{l}2.173 \\
(2.967)\end{array}$ & $\begin{array}{l}-0.002 \\
(0.008)\end{array}$ & $\begin{array}{l}0.008 \\
(0.012)\end{array}$ \\
\hline Education of the household head & $\begin{array}{l}0.003 \\
(0.013)\end{array}$ & $\begin{array}{l}0.905 \\
(5.888)\end{array}$ & $\begin{array}{l}0.069 * * \\
(0.030)\end{array}$ & $\begin{array}{l}0.118 * * * \\
(0.045)\end{array}$ \\
\hline Household size & $\begin{array}{l}0.040 * * \\
(0.017)\end{array}$ & $\begin{array}{l}1.911 \\
(8.210)\end{array}$ & $\begin{array}{l}-0.043 \\
(0.039)\end{array}$ & $\begin{array}{l}-0.031 \\
(0.038)\end{array}$ \\
\hline Access to credit & $\begin{array}{l}0.070 \\
(0.104)\end{array}$ & $\begin{array}{l}-111.220 \\
(76.725)\end{array}$ & $\begin{array}{l}0.296 \\
(0.221)\end{array}$ & $\begin{array}{l}0.231 \\
(0.238)\end{array}$ \\
\hline Extension contact & $\begin{array}{l}0.108 \\
(0.107)\end{array}$ & $\begin{array}{l}-85.704 \\
(61.902)\end{array}$ & $\begin{array}{l}0.253 \\
(0.242)\end{array}$ & $\begin{array}{l}-0.080 \\
(0.263)\end{array}$ \\
\hline Area of cultivation & $\begin{array}{l}-0.034 \\
(0.024)\end{array}$ & $\begin{array}{l}-16.504 \\
(12.669)\end{array}$ & $\begin{array}{l}0.034 \\
(0.079)\end{array}$ & $\begin{array}{l}-0.027 \\
(0.054)\end{array}$ \\
\hline Livestock ownership & $\begin{array}{l}0.016 * \\
(0.009)\end{array}$ & $\begin{array}{l}9.678 \\
(11.961)\end{array}$ & $\begin{array}{l}0.008 \\
(0.019)\end{array}$ & $\begin{array}{l}0.017 \\
(0.020)\end{array}$ \\
\hline Radio ownership & $\begin{array}{l}0.130 \\
(0.109)\end{array}$ & $\begin{array}{l}69.187 \\
(62.426)\end{array}$ & $\begin{array}{l}0.045 \\
(0.258)\end{array}$ & $\begin{array}{l}-0.158 \\
(0.265)\end{array}$ \\
\hline Mobile phone ownership & $\begin{array}{l}0.004 \\
(0.148)\end{array}$ & $\begin{array}{l}17.485 \\
(19.023)\end{array}$ & $\begin{array}{l}0.598 * \\
(0.351)\end{array}$ & $\begin{array}{l}0.133 \\
(0.325)\end{array}$ \\
\hline Constant & $\begin{array}{l}8.395 * * * \\
(0.392)\end{array}$ & $\begin{array}{l}-225.22 \\
(231.32)\end{array}$ & $\begin{array}{l}15.251 \text { *** } \\
(1.003)\end{array}$ & $\begin{array}{l}14.938 * * * \\
(1.218)\end{array}$ \\
\hline F-statistic & $2.30 * * *$ & $16.46^{* * * *}$ & $3.54 * * *$ & $3.25 * * *$ \\
\hline R squared & 0.065 & 0.049 & 0.116 & 0.093 \\
\hline Village fixed effects & Yes & Yes & Yes & Yes \\
\hline Number of observations & 530 & 530 & 530 & 530 \\
\hline
\end{tabular}

*p below $0.1, * * p$ below $0.05, * * * p$ below 0.01 . Standard errors are in parentheses 
Table 14 Effect of ecological shocks on income and asset (full results)

\begin{tabular}{|c|c|c|}
\hline & Income & Assets \\
\hline Prosopis infestation & $\begin{array}{l}-0.311^{* * * *} \\
(0.113)\end{array}$ & $\begin{array}{l}-0.385^{* * *} \\
(0.152)\end{array}$ \\
\hline Parthenium infestation & $\begin{array}{l}0.042 \\
(0.134)\end{array}$ & $\begin{array}{l}-0.090 \\
(0.149)\end{array}$ \\
\hline FAW infestation & $\begin{array}{l}0.089 \\
(0.151)\end{array}$ & $\begin{array}{l}0.014 \\
(0.150)\end{array}$ \\
\hline FAW knowledge & $\begin{array}{l}0.709 * \\
(0.419)\end{array}$ & $\begin{array}{l}0.714 \\
(0.557)\end{array}$ \\
\hline Age of the household head & $\begin{array}{l}-0.002 \\
(0.004)\end{array}$ & $\begin{array}{l}-0.001 \\
(0.005)\end{array}$ \\
\hline Education of the household head & $\begin{array}{l}0.064 * * * \\
(0.009)\end{array}$ & $\begin{array}{l}0.064 * * * \\
(0.015)\end{array}$ \\
\hline Household size & $\begin{array}{l}0.013 \\
(0.016)\end{array}$ & $\begin{array}{l}0.094 * * * \\
(0.024)\end{array}$ \\
\hline Access to credit & $\begin{array}{l}0.143 * * \\
(0.081)\end{array}$ & $\begin{array}{l}0.173 \\
(0.129)\end{array}$ \\
\hline Extension contact & $\begin{array}{l}-0.074 \\
(0.105)\end{array}$ & $\begin{array}{l}0.100 \\
(0.143)\end{array}$ \\
\hline Area of cultivation & $\begin{array}{l}0.019 \\
(0.020)\end{array}$ & $\begin{array}{l}-0.003 \\
(0.039)\end{array}$ \\
\hline Livestock ownership & $\begin{array}{l}0.050 * * * \\
(0.007)\end{array}$ & $\begin{array}{l}0.085 * * * \\
(0.021)\end{array}$ \\
\hline Radio ownership & $\begin{array}{l}0.229 * * \\
(0.100)\end{array}$ & $\begin{array}{l}0.499 * * * \\
(0.136)\end{array}$ \\
\hline Mobile phone ownership & $\begin{array}{l}0.345 * * \\
(0.173)\end{array}$ & $\begin{array}{l}0.646 * * * \\
(0.225)\end{array}$ \\
\hline Constant & $\begin{array}{l}7.001 * * * \\
(0.451)\end{array}$ & $\begin{array}{l}7.279 * * * \\
(0.616)\end{array}$ \\
\hline$F$-statistic & $16.50 * * *$ & $12.75 * * *$ \\
\hline$R$ squared & 0.312 & 0.382 \\
\hline Village fixed effects & Yes & Yes \\
\hline Number of observations & 530 & 530 \\
\hline
\end{tabular}

$* p$ below $0.1, * * p$ below $0.05, * * * p$ below 0.01 . standard errors are in parentheses 
Table 15 Effect of ecological shocks on aspiration index, income aspiration, and asset aspiration (full estimates of IV regression)

\begin{tabular}{|c|c|c|c|}
\hline & Aspiration index & Income aspirations & Asset aspirations \\
\hline Prosopis infestation & $\begin{array}{l}-9.772 * * * \\
(4.360)\end{array}$ & $\begin{array}{l}-0.448 * * * \\
(0.351)\end{array}$ & $\begin{array}{l}-1.010 * * * \\
(0.326)\end{array}$ \\
\hline Parthenium infestation & $\begin{array}{l}-0.761 \\
(1.224)\end{array}$ & $\begin{array}{l}0.056 \\
(0.078)\end{array}$ & $\begin{array}{l}0.020 \\
(0.106)\end{array}$ \\
\hline FAW infestation & $\begin{array}{l}-0.581 \\
(1.648)\end{array}$ & $\begin{array}{l}-0.130 \\
(0.105)\end{array}$ & $\begin{array}{l}-0.086 \\
(0.143)\end{array}$ \\
\hline FAW knowledge & $\begin{array}{l}-5.915^{* * *} \\
(3.028)\end{array}$ & $\begin{array}{l}-0.183 \\
(0.194)\end{array}$ & $\begin{array}{l}-0.070 \\
(0.263)\end{array}$ \\
\hline Age of the household head & $\begin{array}{l}-0.060 \\
(0.046)\end{array}$ & $\begin{array}{l}-0.004 * \\
(0.003)\end{array}$ & $\begin{array}{l}-0.004 \\
(0.004)\end{array}$ \\
\hline Education of the household head & $\begin{array}{l}0.446 * * * \\
(0.149)\end{array}$ & $\begin{array}{l}0.054 * * * \\
(0.009)\end{array}$ & $\begin{array}{l}0.044 * * * \\
(0.013)\end{array}$ \\
\hline Household size & $\begin{array}{l}-0.061 \\
(0.211)\end{array}$ & $\begin{array}{l}-0.003 \\
(0.013)\end{array}$ & $\begin{array}{l}0.048^{* * * *} \\
(0.018)\end{array}$ \\
\hline Access to credit & $\begin{array}{l}1.163 \\
(1.157)\end{array}$ & $\begin{array}{l}0.008 \\
(0.074)\end{array}$ & $\begin{array}{l}0.246^{* *} \\
(0.102)\end{array}$ \\
\hline Extension contact & $\begin{array}{l}0.893 \\
(1.271)\end{array}$ & $\begin{array}{l}0.134 * \\
(0.081)\end{array}$ & $\begin{array}{l}0.119 \\
(0.111)\end{array}$ \\
\hline Area of cultivation & $\begin{array}{l}0.867 * * \\
(0.344)\end{array}$ & $\begin{array}{l}0.026 \\
(0.022)\end{array}$ & $\begin{array}{l}0.025 \\
(0.030)\end{array}$ \\
\hline Livestock ownership & $\begin{array}{l}0.350 * * * \\
(0.122)\end{array}$ & $\begin{array}{l}0.020 * * * \\
(0.007)\end{array}$ & $\begin{array}{l}0.040 * * * \\
(0.010)\end{array}$ \\
\hline Radio ownership & $\begin{array}{l}0.829 \\
(1.224)\end{array}$ & $\begin{array}{l}0.021 \\
(0.078)\end{array}$ & $\begin{array}{l}0.047 \\
(0.106)\end{array}$ \\
\hline Mobile phone ownership & $\begin{array}{l}1.722 \\
(1.532)\end{array}$ & $\begin{array}{l}0.075 \\
(0.098)\end{array}$ & $\begin{array}{l}-0.048 \\
(0.133)\end{array}$ \\
\hline Constant & $\begin{array}{l}-19.142 * * * \\
(4.933)\end{array}$ & $\begin{array}{l}8.879 * * * \\
(0.331\end{array}$ & $\begin{array}{l}9.183 * * * \\
(0.429)\end{array}$ \\
\hline F-statistic & $4.69^{* * *}$ & $26.56 * * *$ & $8.39^{* * *}$ \\
\hline Village fixed effects & Yes & Yes & Yes \\
\hline Number of observations & 530 & 530 & 530 \\
\hline
\end{tabular}

*p below $0.1,{ }^{* *} p$ below $0.05, * * * p$ below 0.01 . Standard errors are in parentheses 
Table 16 Effect of ecological shocks on livestock, status, and educational aspirations (full estimates of IV regression)

\begin{tabular}{|c|c|c|c|c|}
\hline & \multirow[t]{2}{*}{ Livestock aspirations } & \multirow[t]{2}{*}{ Status aspirations } & \multicolumn{2}{|c|}{ Educational aspirations } \\
\hline & & & Boys & Girls \\
\hline Prosopis infestation & $\begin{array}{l}-50.711 \\
(147.546)\end{array}$ & $\begin{array}{l}-0.420 \\
(0.395)\end{array}$ & $\begin{array}{l}-1.021 \\
(1.103)\end{array}$ & $\begin{array}{l}-0.139 \\
(1.026)\end{array}$ \\
\hline Parthenium infestation & $\begin{array}{l}99.380 \\
(60.870)\end{array}$ & $\begin{array}{l}0.156 \\
(0.109)\end{array}$ & $\begin{array}{l}0.187 \\
(0.234)\end{array}$ & $\begin{array}{l}0.166 \\
(0.240)\end{array}$ \\
\hline FAW infestation & $\begin{array}{l}43.940 \\
(81.490)\end{array}$ & $\begin{array}{l}0.138 \\
(0.147)\end{array}$ & $\begin{array}{l}0.098 \\
(0.316)\end{array}$ & $\begin{array}{l}0.205 \\
(0.324)\end{array}$ \\
\hline FAW knowledge & $\begin{array}{l}-7.577 \\
(150.686)\end{array}$ & $\begin{array}{l}-0.174 \\
(0.271)\end{array}$ & $\begin{array}{l}-0.535 \\
(0.579)\end{array}$ & $\begin{array}{l}-0.417 \\
(0.595)\end{array}$ \\
\hline Age of the household head & $\begin{array}{l}2.177 \\
(2.289)\end{array}$ & $\begin{array}{l}0.009 \\
(0.041)\end{array}$ & $\begin{array}{l}-0.002 \\
(0.008)\end{array}$ & $\begin{array}{l}0.008 \\
(0.009)\end{array}$ \\
\hline Education of the household head & $\begin{array}{l}0.931 \\
(7.429)\end{array}$ & $\begin{array}{l}0.003 \\
(0.013)\end{array}$ & $\begin{array}{l}0.069 * \\
(0.028)\end{array}$ & $\begin{array}{l}0.118 * * * \\
(0.029)\end{array}$ \\
\hline Household size & $\begin{array}{l}1.783 \\
(10.522)\end{array}$ & $\begin{array}{l}0.039 * * \\
(0.019)\end{array}$ & $\begin{array}{l}-0.044 \\
(0.040)\end{array}$ & $\begin{array}{l}-0.030 \\
(0.041)\end{array}$ \\
\hline Access to credit & $\begin{array}{l}-112.234 * * \\
(57.385)\end{array}$ & $\begin{array}{l}0.064 \\
(0.103)\end{array}$ & $\begin{array}{l}0.281 \\
(0.222)\end{array}$ & $\begin{array}{l}0.234 \\
(0.227)\end{array}$ \\
\hline Extension contact & $\begin{array}{l}-86.212 \\
(63.154)\end{array}$ & $\begin{array}{l}0.105 \\
(0.114)\end{array}$ & $\begin{array}{l}0.246 \\
(0.243)\end{array}$ & $\begin{array}{l}-0.079 \\
(0.249)\end{array}$ \\
\hline Area of cultivation & $\begin{array}{l}-16.599 \\
(17.126)\end{array}$ & $\begin{array}{l}-0.035 \\
(0.030)\end{array}$ & $\begin{array}{l}0.033 \\
(0.065)\end{array}$ & $\begin{array}{l}-0.027 \\
(0.067)\end{array}$ \\
\hline Livestock ownership & $\begin{array}{l}9.629 \\
(6.081)\end{array}$ & $\begin{array}{l}0.016 \\
(0.010)\end{array}$ & $\begin{array}{l}0.007 \\
(0.023)\end{array}$ & $\begin{array}{l}0.017 \\
(0.024)\end{array}$ \\
\hline Radio ownership & $\begin{array}{l}69.716 \\
(60.911)\end{array}$ & $\begin{array}{l}0.133 \\
(0.109)\end{array}$ & $\begin{array}{l}0.053 \\
(0.234)\end{array}$ & $\begin{array}{l}-0.159 \\
(0.240)\end{array}$ \\
\hline Mobile phone ownership & $\begin{array}{l}17.572 \\
(76.262)\end{array}$ & $\begin{array}{l}0.004 \\
(0.137)\end{array}$ & $\begin{array}{l}0.599 \\
(0.293)\end{array}$ & $\begin{array}{l}0.132 \\
(0.301)\end{array}$ \\
\hline Constant & $\begin{array}{l}-207.122 \\
(239.536)\end{array}$ & $\begin{array}{l}8.489 * * * \\
(0.447)\end{array}$ & $\begin{array}{l}15.505 * * * \\
(0.995)\end{array}$ & $\begin{array}{l}14.904 * * * \\
(1.008)\end{array}$ \\
\hline$F$-statistic & $8.65 * * *$ & $20.36 * * *$ & $6.32 * * *$ & 7.26 \\
\hline Village fixed effects & Yes & Yes & Yes & Yes \\
\hline Number of observations & 530 & 530 & 530 & 530 \\
\hline
\end{tabular}

$* p$ below $0.1, * * p$ below $0.05, * * * p$ below 0.01 . standard errors are in parentheses

Table 17 Correlation between Prosopis infestation and soil type

\begin{tabular}{lll}
\hline & Prosopis infestation & Soil type \\
\hline Prosopis infestation & 1.0000 & \\
Soil type & $0.2543^{* * *}$ & 1.0000 \\
\hline
\end{tabular}

* $p$ below $0.1,{ }^{* *} p$ below $0.05,{ }^{* * *} p$ below 0.01 
Table 18 Regression coefficient of soil type in outcome equations
Outcomes

Coefficient

of soil type

\begin{tabular}{ll}
\hline Aspiration index & 0.563 \\
& $(0.497)$ \\
Income aspiration & -0.004 \\
& $(0.031)$ \\
Asset aspiration & -0.022 \\
Livestock aspirations & $(0.048$ \\
& -7.373 \\
Status aspiration & $(7.212)$ \\
Educational aspiration & -0.026 \\
& $(0.079)$ \\
& -0.048 \\
\hline
\end{tabular}

${ }^{*} p$ below $0.1, * * p$ below $0.05, * * * p$ below 0.01

Acknowledgements This research was supported by the German Research Foundation (DFG) through funding for the project "Invasive futures" as part of the Collaborative Research Center "Future Rural Africa" (Project-ID 328966760_TRR 228). We are grateful to Emmanuel Nshakira-Rukundo and Adam Kurczewski for their support in data collection. We also thank the team of enumerators and Julius Ngilip for his assistance during pre-surveys, the household listing exercise, and the entire data collection process. An earlier version of this paper was presented at the 2020 AAEA virtual meeting in Kansas City, USA. The authors appreciate the comments and constructive feedback of two anonymous reviewers. The usual disclaimer applies.

Funding Open Access funding enabled and organized by Projekt DEAL.

\section{Declarations}

Conflict of interest The authors declare that they have no conflict of interest.

Open Access This article is licensed under a Creative Commons Attribution 4.0 International License, which permits use, sharing, adaptation, distribution and reproduction in any medium or format, as long as you give appropriate credit to the original author(s) and the source, provide a link to the Creative Commons licence, and indicate if changes were made. The images or other third party material in this article are included in the article's Creative Commons licence, unless indicated otherwise in a credit line to the material. If material is not included in the article's Creative Commons licence and your intended use is not permitted by statutory regulation or exceeds the permitted use, you will need to obtain permission directly from the copyright holder. To view a copy of this licence, visit http://creativecommons.org/licen ses/by/4.0/.

\section{References}

Appadurai, Arjun (Ed.). 2004. The Capacity to Aspire: Culture and the Terms of Recognition. The World Bank. Wahington, DC: Stanford University Press (Culture and Public Action).

Aryal, J.P., and S.T. Holden. 2012. Livestock and land share contracts in a Hindu society. Agricultural Economics 43 (5): 593-606. 
Baudron, F., M.A. Zaman-Allah, I. Chaipa, N. Chari, and P. Chinwada. 2019. Understanding the factors influencing fall armyworm (Spodoptera frugiperda J.E. Smith) damage in African smallholder maize fields and quantifying its impact on yield. A case study in Eastern Zimbabwe. Crop Protection 120: 141-150.

Beaman, L., E. Duflo, R. Pande, and P. Topalova. 2012. 'Female leadership raises aspirations and educational attainment for girls: A policy experiment in India. Science New York NY 335 (6068): 582-586.

Bekele, K., J. Haji, B. Legesse, and U. Schaffner. 2018. Economic impacts of Prosopis spp. invasions on dryland ecosystem services in Ethiopia and Kenya: Evidence from choice experimental data. Journal of Arid Environments 158 (1): 9-18.

Bernard, T., S. Dercon, K. Orkin, and A.S. Taffesse. 2019. 'Parental aspirations for children's education: Is there a "Girl Effect"? Experimental evidence from Rural Ethiopia. AEA Papers and Proceedings 109: 127-132.

Bernard, T., and Alemayehu Seyoum Taffesse. 2014. Aspirations. An approach to measurement with validation using ethiopian data. Journal of African Economies 23 (2): 189-224. https://doi.org/10.1093/ jae/ejt030.

CABI. 2019. Invasive Species Compendium. Detailed coverage of invasive species threatening livelihoods and the environment worldwide. Available online at https://www.cabi.org/isc/datasheet/ 45573\#2c3805d1-a85c-4ae7-b339-e06e911ab700.

Debela, B.L. 2017. Factors affecting differences in livestock asset ownership between male- and female-headed households in Northern Ethiopia. The European Journal of Development Research 29 (2): 328-347.

Dercon, S., and D. Gollin. 2014. Agriculture in African development: Theories and strategies. Annual Review of Resource Economics 6 (1): 471-492.

Groote, De., Kimenju Hugo, C. Simon, Bernard Munyua, Sebastian Palmas, Menale Kassie, and Anani Bruce. 2020. Spread and impact of fall armyworm (Spodoptera frugiperda J.E. Smith) in maize production areas of Kenya. Agriculture Ecosystems \& Environment 292: 106804.

FAO. 2018. Integrated management of the fall armyworm on maize. A guide for farmer field schools in Africa. Rome: FAO.

Haushofer, J., and E. Fehr. 2014. On the psychology of poverty. Science (New York, N.Y.) 344 (6186): 862-867.

Janzen, Sarah A., Nicholas Magnan, Sudhindra Sharma, and William M. Thompson. 2017. Aspirations failure and formation in rural Nepal. Journal of Economic Behavior \& Organization 139: 1-25. https://doi.org/10.1016/j.jebo.2017.04.003.

Jensen, Robert. 2000. Agricultural Volatility and Investments in Children. American Economic Review 90 (2): 399-404.

Kassie, M., T. Wossen, H. de Groote, T. Tefera, S. Sevgan, and S. Balew. 2020. Economic impacts of fall armyworm and its management strategies: Evidence from southern Ethiopia. European Review of Agricultural Economics 47 (4): 1473-1501.

Knight, John, and Ramani Gunatilaka. 2012. Income, aspirations and the Hedonic Treadmill in a poor society. Journal of Economic Behavior \& Organization 82 (1): 67-81. https://doi.org/10.1016/j. jebo.2011.12.005.

Kosec, Katrina, and Cecilia Hyunjung Mo. 2017. Aspirations and the role of social protection. Evidence from a natural disaster in Rural Pakistan. World Development 97: 49-66. https://doi.org/10.1016/j. worlddev.2017.03.039.

Laajaj, Rachid. 2017. Endogenous time horizon and behavioral poverty trap: Theory and evidence from Mozambique. Journal of Development Economics 127: 187-208.

LaRue, Katie, Thomas Daum, Kai Mausch, and Dave Harris. 2021. Who wants to farm? Answers depend on how you ask: a case study on youth aspirations in Kenya. European Journal of Development Research 10: 2. https://doi.org/10.1057/s41287-020-00352-2.

Macours, Karen, and Renos Vakis. 2014. Changing households' investment behaviour through social interactions with local leaders: Evidence from a randomised transfer programme. Economic Journal 124 (576): 607-633.

Mausch, K., D. Harris, E. Heather, E. Jones, J. Yim, and M. Hauser. 2018. Households' aspirations for rural development through agriculture. Outlook Agric 3 (9): 003072701876694. https://doi.org/10. $1177 / 0030727018766940$.

Mbaabu, Purity Rima, Wai-Tim. Ng, Urs Schaffner, Maina Gichaba, Daniel Olago, Simon Choge, et al. 2019. Spatial evolution of prosopis invasion and its effects on LULC and livelihoods in Baringo, Kenya. Remote Sensing 11 (10): 1217. https://doi.org/10.3390/rs11101217. 
Mekonnen, D.A., and N. Gerber. 2017. Aspirations and food security in rural Ethiopia. Food Security. 9: 371-385. https://doi.org/10.1007/s12571-017-0654-6.

Mwangi, E., and B. Swallow. 2008. Prosopis juliflora Invasion and Rural Livelihoods in the Lake Baringo Area of Kenya. Conservation and Society 6 (2): 130-140.

Pratt, Corin F., Kate L. Constantine, and Sean T. Murphy. 2017. Economic impacts of invasive alien species on African smallholder livelihoods. Global Food Security 14: 31-37. https://doi.org/10.1016/j. gfs.2017.01.011.

Rao, Nitya, Chandni Singh, Divya Solomon, Laura Camfield, Rahina Sidiki, Margaret Angula, Prathigna Poonacha, Amadou Sidibé, and Elaine T. Lawson. 2020. Managing risk, changing aspirations and household dynamics: Implications for wellbeing and adaptation in semi-arid Africa and India. World Development 125: 104667.

Serneels, Pieter, and Stefan Dercon. 2021. Aspirations, poverty, and education evidence from India. The Journal of Development Studies 57 (1): 163-183. https://doi.org/10.1080/00220388.2020.1806242.

Stutzer, Alois. 2004. The role of income aspirations in individual happiness. Journal of Economic Behavior \& Organization 54 (1): 89-109. https://doi.org/10.1016/j.jebo.2003.04.003.

Publisher's Note Springer Nature remains neutral with regard to jurisdictional claims in published maps and institutional affiliations. 